\title{
PRIMARY LYMPHOMA OF THE CENTRAL NERVOUS SYSTEM
}

\section{A clinical-pathological and immunohistochemical study of ten autopsy cases}

\author{
Henrique Costa ${ }^{1}$, Marcello Franco ${ }^{2}$, Myriam Dumas Hahn ${ }^{3}$
}

\begin{abstract}
Context:Primary central nervous system lymphomas (PCNSL) are a rare subgroup of lymphomas generally associated with HIV and EBV. Objective: To study ten autopsy cases of PCNSL, to describe the neuropathological findings, to characterize the phenotype of the neoplastic cells, to detect EBV in the lesion and to compare the findings with the clinical and laboratory data of the patients. Method: The clinical, histological and immunohistochemical data of ten cases of PCNSL, eight cases from patients with AIDS, identified among 265 autopsies of these patients were analyzed. Results: Seven patients were males and the mean age was 40.9 years. The most frequent symptomatology was focal neurologic deficit (70\%). Six patients presented with only one lesion. Histologically, densely cellular and polymorphous neoplasms with angiocentrism were observed, in $90 \%$ of cases. An association with other diseases was observed in four cases. Most patients had diffuse large B cell non-Hodgkin's lymphoma. EBV was detected by immunohistochemistry in only one case. The lack of detection of the virus might have been due to the long time of fixation of the brain which might have inactivate epitopes therefore compromising the testing. Conclusion: In the present series, PCNSL presented with focal symptoms, with unifocal or multifocal lesions, with a predominant B-cell CD20 positive phenotype, rarely associated with EBV.
\end{abstract}

KEY WORDS: primary central nervous system lymphoma, neuropathology, immunohistochemistry, acquired immunodeficiency syndrome.

\begin{abstract}
Linfoma primário do sistema nervoso central: estudo clínico-patológico e imuno-histoquímico de dez casos de necropsia

RESUMO - Contexto: Linfoma primário do sistema nervoso central (LP-SNC) é raro subgrupo de linfomas relacionado à AIDS, geralmente associado EBV. Objetivo: Identificar os achados clínico-patológicos dos pacientes com LP-SNC. Método: Foram analisados dados clínicos, histológicos e imuno-histoquímicos de dez necrópsias de LP-SNC, oito deles de pacientes com AIDS, identificados entre 265 autopsias destes. Resultados: Sete pacientes foram masculinos e a idade média foi 40,9 anos. A sintomatologia neurológica mais freqüente era focal (70\%). Seis exibiram lesão única. Histologicamente, eram neoplasias densamente celulares e polimorfas, com angiocentrismo em $90 \%$ dos casos. Em quatro casos, houve associação com outras afecções. A maioria dos casos foi de linfoma não-Hodgkin difuso de grandes células B. A pesquisa para EBV foi positiva em um caso. Conclusão: P redominaram os LP-SNC associados à AIDS, com sintomatologia focal, lesão em massa ou multifocal, com predominância de células B CD-20.
\end{abstract}

PALAVRAS-CHAVE: linfoma primário do sistema nervoso central, achados neuropatológicos, imuno-histoquímica, síndrome da imunodeficiência adquirida.

Primary central nervous system lymphomas (PCNSL) a re a rare group of neoplasms, accounting for about 0.3 to $1.5 \%$ of all intracranial tumors and for 0.7 to $2 \%$ of lymphomas'. These tumors are generally associated with immunosuppression due to either the use of immunosuppressive drugs ${ }^{2}$, human immunodeficiency virus (HIV) infection ${ }^{3,4}$ or congenital disorders such as Wiskott-Aldrich syndrome ${ }^{5}$. PCNSL differ from extranodal lymphomas in terms of patient survival, p redisposing factors, histological subtypes and diff $\mathrm{i}-$

'Department of Pathology, State University of Health Sciences of Alagoas - UNCISAL, Maceió AL - Brazil; ${ }^{2}$ Department of Pathology, Paulista School of Medicine of Federal University of São Paulo - UNIFESP/EPM, São Paulo SP - Brazil; ${ }^{3} D$ e p a rtment of Pathology, Federal University Fluminense - UFF, Niterói RJ - Brazil.

Received 20 February 2006, received in final form 21 June 2006. Accepted 28 July 2006.

Dr. Henrique de Oliveira Costa - Departamento de Patologia / EPMIUNIFESP - Rua Botucatu 740 - 04023-900 São Paulo SP - Brasil. E-mail: lapac@uol.com.br 
culties in the classification according to the Working Fo rmulation, the Kiel criteria and the revised European-American Lymphoma (REAL) system. In view of their restriction to a non-lymphoid organ, among other reasons, PCNSL have been considered a separate entity whose prognosis is generally worse than that of systemic lymphomas ${ }^{6}$. With the advent of AIDS and the introduction of organ transplants, the incidence of PCNSL has been increasing. These tumors currently represent an important subgroup of lymphomas $^{2,4}$. In patients with AIDS, PCNSL are the second most common lesion with a mass effect ${ }^{4}$ and the most frequent noninfectious cause of death ${ }^{7}$. The tumor represents the fourth cause of death in this $g$ roup of patients ${ }^{8}$. PCNSL show a male/female ratio of 1.5 to 1 , whereas the T subtype presents a ratio of $7: 1^{9}$. The clinical manifestations are indistinguishable from cerebral toxoplasmosis and include loss of consciousness and focal neurologic deficits ${ }^{10}$. In the case of meningeal involvement, the tumor manifests as a meningeal syndrome ${ }^{11,12}$. Most PCNSL involve the basal nuclei or the frontal and parietal lobes, and present as homogenous mass lesions with ring-like zone of contrast enhancement and perilesional edema. The neuroimaging diff e rential diagnosis with cerebral toxoplasmosis is difficult ${ }^{10}$. The lesions are multifocal, bilateral or periventricular and may extend to the subarachnoid space or ventricular cavity ${ }^{13}$. The macroscopic findings are variable ${ }^{14}$. Some tumors present as well-defined masses with a homogenous cut surface. Other lesions are poorly demarcated, diffusely infiltrating, showing areas of softening, hemorrhage and necrosis ${ }^{15}$. In immunocompetent patients, PCNSL are more superficial and located in the white and/or gray matter ${ }^{16}$, or exclusively in the subarachnoid space ${ }^{17}$.

The histopathological findings of PCNSL are similar to those of systemic non-Hodgkin's lymphomas and include densely cellular lesions comprised by atypical lymphoid cells ${ }^{13}$ with an angiocentric pattern at the margins of the infiltrate and a rich reticulin network dissociating the vascular wall ${ }^{18}$. In voluminous tumors, the areas of necrosis can be extensive. Mitotic activity is high and hemorrhage is common. Neoplastic cells may invade normal adjacent structures. Therefore subependymal infiltration extending into the ventricular cavity and subarachnoid space are not uncommon ${ }^{14}$. The oncogenesis of PCNSL is still controversial. The site of origin of these lymphomas and the oncogenetic mechanisms are still unclear, especially because the tumor develops from and is restricted to a non-lymphoid organ without lymphatic vessels ${ }^{19}$. It might occur due to the development of a monoclonal proliferation from a preexisting inflammatory lesion, similar to the mechanism underlying the origin of MALT lymphoma from Helicobacter pylori-induced gastritis. This hypothesis is supported by the demonstration of inflammatory lesions preceding the development of PCNSL ${ }^{20,21}$. Other authors suggest that non-neoplastic lymphocytes might be targeted to the CNS by a viral infection, more notably HTLV-1 or EBV, with the possible later occurrence of clonal neoplastic transformation of these cells ${ }^{12}$. In the case of immunodepressed patients, one may speculate that the lack of control of $T$ cells over EBV present in patients with AIDS promotes the reactivation of EBV infection, leading to the proliferation of $B$ cells, induction of oncogenes and gene rea rrangements, and finally to the development of PCNSL ${ }^{22}$. There fo re in patients with AIDS, infection with EBV is suggested to be the most likely oncogenetic mechanisms since the EBV genome is found in more than $95 \%$ of these tumors and in less of $20 \%$ of PCNSL not associated with AIDS ${ }^{23-25}$. Herpes virus genomes such as HHV-6 or HHV-8 have been identified in some cases, suggesting that these or other herpes viruses may predispose to the development of primary lymphoma, even in immunocompetent patients ${ }^{23}$. HIV-infected subjects show a 60 to 100 times higher risk of developing malignant lymphoma, which represents a diagnostic criterion for AIDS $^{5}$.

Based on the above observations, we studied ten autopsy cases of PCNSL to more accurately describe the neuropathological findings and to characterize the phenotype of the neoplastic cells, to test the presence of EBV and to compare the morphological findings with the clinical and laboratory data of the patients.

\section{METHOD}

A total of 265 autops ies of patients perf o rmed at the Senice of Pathological Anatomy, Department of Pathology, Antônio Pedro University Hospital, Federal University Fluminense, between 1987 and 1996 were revised and 10 cases of PCNSL were selected (3.7\%).

Preparation of the material and fixation - The autopsy was complete in all cases and the CNS was fixed in $30 \%$ formalin for 21 days and then examined. The cerebral hemisphereswere studied in approximately $1.0-\mathrm{cm}$ thick coronal sections and in $0.5-$ to $1.0-\mathrm{cm}$ perpendicular sections cut from the cerebral trunk and cerebellar hemispheres.

Fragments re $p$ resentative of the lesions were embedded in paraffin, cut into $5-\mu \mathrm{m}$ thick sections, stained with hematoxylin-eosin and for reticulin fibers. 
Table 1. Panel of antibodies.

\begin{tabular}{|c|c|c|c|c|c|c|}
\hline $\begin{array}{l}\text { Primary } \\
\text { antibody }\end{array}$ & Diluition & Source & Code & Origin & $\begin{array}{l}\text { Secundary } \\
\text { antibodies }\end{array}$ & $\begin{array}{l}\text { Antigen retrieval } \\
\text { procedure }\end{array}$ \\
\hline CD30 & $1 / 100$ & Dako & M 751 & Mouse & $\mathrm{R} \times \mathrm{M}$ * & Trypsin \\
\hline CD15 & $1 / 150$ & Dako & M 733 & Mouse & $\mathrm{R} \times \mathrm{M}$ * & $M W / P C^{*}$ \\
\hline CD3 & $1 / 200$ & Dako & A 0452 & Rabbit & $G \times R^{* * *}$ & MW/PC* \\
\hline CD20 & $1 / 250$ & Dako & M 0755 & Mouse & $\mathrm{R} \times \mathrm{M}$ * & MW/PC* \\
\hline Kappa & $1 / 4000$ & Sigma & K-4377 & Mouse & $\mathrm{R} \times \mathrm{M}$ * & MW/PC* \\
\hline Lambda & $1 / 4000$ & Sigma & L-6522 & Mouse & $\mathrm{R} \times \mathrm{M}$ * & MW/PC* \\
\hline EBV & $1 / 2500$ & Dako & M 0897 & Mouse & $R \times M$ * & MW/PC* \\
\hline CMV & $1 / 100$ & Dako & M 854 & Mouse & $\mathrm{R} \times \mathrm{M}$ * & Trypsin \\
\hline GFAP & $1 / 400$ & Dako & Z 0334 & Rabbit & $G \times R^{* * *}$ & Trypsin \\
\hline
\end{tabular}

*Ig Rabbit anti-Ig Mouse; **MW/PP, Microwave/Pressure chamber; ***Ig Goat anti-lg Rabbit.

Immunohistochemistry- 5-um thick CNS sections were mounted on slides previously treated with 3-aminopropyItriethoxysilane (Sigma, A3648). After incubation in an oven at $60^{\circ} \mathrm{C}$ for about $18 \mathrm{~h}$, the sections were deparaffinized in xylene and hydrated in decreasing ethanol concentrations. Next, the specimens were incubated in two baths of $3 \%$ oxygenated water in methanol for 15 min each to inhibit endogenous peroxidase and washed with Tris buffer, $\mathrm{pH}$ 7.4. For antigen retrieval, the sections were immersed in citrate buffer, $\mathrm{pH} 6.0$, and heated in a microwave oven for $5 \mathrm{~min}$ at maximum potency. Pressure chamber was used to CD3, CD20, CD15, KAPPA, LAMBDA e EBV antibodies. To inhibit nonspecific binding, the sections were incubated in a Tris-buffered solution of $1 \%$ skim milk $(\mathrm{w} / \mathrm{v})$ and $1 \%$ bovine serum albumin $(\mathrm{w} / \mathrm{v})$ in a humid chamber for $1 \mathrm{~h}$ at room temperature. Next, the sections were incubated overnight in a humid chamber at $4^{\circ} \mathrm{C}$ with the following prima ry antibodies: rabbit anti-human CD3 polyclonal (Dako, A 0452, diluted 1/200), mouse anti-human CD20 monoclonal (Dako, M 0755, diluted 1/250), mouse anti-human CD15 (Dako, M 733, diluted 1/150), mouse anti-human Kappa monoclonal (Sigma, K-4377, diluted 1/4000), mouse antihuman Lambda monoclonal (Sigma, L-6522, diluted 1/4000), and mouse anti-EBV monoclonal (Dako, M 0897, diluted 1/2500).

For the anti-CD30, anti-CMV and anti-GFAP antibodies, the sections were trypsinized, nonspecific binding of the antibodies was blocked and the specimens were incubated in a humid chamber at $37^{\circ} \mathrm{C}$ with the following primary antibodies: mouse anti-human CD30 monoclonal antibody (Dako, M 751, diluted 1/100), mouse anti-CMV monoclonal antibody (Dako, $M$ 854, diluted 1/100), and rabbit antiGFAP polyclonal antibody (Dako, Z 0334, diluted 1/400).

Next, the sections were washed three times in Tris buffer for $10 \mathrm{~min}$ each and incubated with the biotinylated secondary antibodies: goat anti-rabbit immunoglobulins (Dako, E 432, diluted $1 / 200$ ) or rabbit anti-mouse immunoglobulins (Dako, E 0354, diluted 1/200) for $1 \mathrm{~h}$ in a humid chamber at $37^{\circ} \mathrm{C}$. The primary and secondary antibodies were diluted in Tris-buffered $1 \%$ bovine serum albumin (w/v). After three washes in Tris buffer for $10 \mathrm{~min}$ each, the sec- tions were incubated with thestreptavidin-biotin-peroxidase complex (Dako, K 0377) for 45 min in a humid chamber at room temperature, washed again three times in Tris buffer, and the peroxidase reaction was developed with diaminobenzidine (Sigma, 5637) and oxygenated water. The sections were counterstained with Mayer's hematoxylin. The antibodies used are shown in Table 1.

\section{RESULTS}

General clinical data and laboratory exams - The gender, age, risk behavior, clinical data and complementary exams of the patients are summarized in Table 2 . Seven patients were males and three were females, with age ranging from 24 to 64 years (mean \pm tandard deviation: $40.9 \pm 11.8$ years). Neurological signs or symptoms were observed in all but one case, with a predominance of focal neurological deficit in seven patients. The time between the discovery of HIV positivity and the diagnosis of PCNSL ranged from 6 months to 3 years.

$G$ ross findings - B rown-grayish, poorly demarcated lesions with areas of necrosis, comprised by soft, fleshy to friable tissue, were identified in the basal nuclei (Fig 1) and thalamus of six, in the cerebral t runk of four, in the cerebellar hemisphere of three, and in the cortex and corpus callosum of two patients. Multiple lesions were observed in six cases, with the number of lesions ranging from 2 to 4 . In three cases, only one lesion was identified.

In one case, the gross findings differed from those observed in other cases. The tumor lesion was characterized by a whitish color and homogenous surf ace with a fish-flesh appearance, and involved structures of the midline and deep gray matter, extending to the corpus callosum and adjacent white matter (Fig 2). Another case was characterized by the enlargement of the nerve roots and cranial nerves, and opacity of the leptomeninges. Analysis of the 
Table 2. Identification, clinical data, risk behavior and complementary exams of 10 autopsy cases of CNS primary lymphoma diag nosed.

\begin{tabular}{|c|c|c|c|c|c|c|c|}
\hline Case & $\begin{array}{l}\text { Age } \\
(\mathrm{Y} / \mathrm{O})\end{array}$ & Gender & Risk behavior & HIV & $\begin{array}{l}\text { Time of } \\
\text { evolution } \\
\text { (months) }\end{array}$ & Clinical data & Neurological signs \\
\hline $\begin{array}{c}1 \\
\text { N87-297 }\end{array}$ & 64 & $\mathrm{~F}$ & Hemotransfusion & + & 10 & $\begin{array}{l}\text { Loss weight, fever, } \\
\text { diarrhea, hemorrhage }\end{array}$ & $\begin{array}{l}\text { Focal neurologic deficit, } \\
\text { convulsion, coma }\end{array}$ \\
\hline $\begin{array}{c}2 \\
N 88-422\end{array}$ & 35 & M & NE & + & NE & $\begin{array}{l}\text { Loss weight, fever, } \\
\text { diarrhea, pulmonary } \\
\text { infection }\end{array}$ & No neurological signs. \\
\hline $\begin{array}{c}3 \\
N 89-009\end{array}$ & 46 & M & Promiscuous & + & 12 & $\begin{array}{l}\text { Loss weight, fever, } \\
\text { diarrhea, pneumocystosis }\end{array}$ & $\begin{array}{l}\text { Paraplegy, dysfunction } \\
\text { of sphincter }\end{array}$ \\
\hline $\begin{array}{c}4 \\
N 89-224\end{array}$ & 28 & M & NE & + & 12 & $\begin{array}{l}\text { Loss weight, fever, } \\
\text { diarrhea, pneumocystosis, } \\
\text { Kaposi's sarcoma }\end{array}$ & $\begin{array}{l}\text { Meningeal syndrome, } \\
\text { coma }\end{array}$ \\
\hline $\begin{array}{c}5 \\
N 91-013\end{array}$ & 38 & M & NE & + & 8 & $\begin{array}{l}\text { Loss weight, fever, } \\
\text { diarrhea, pneumocystosis }\end{array}$ & $\begin{array}{l}\text { Focal neurologic deficit, } \\
\text { meningeal syndrome }\end{array}$ \\
\hline $\begin{array}{c}6 \\
N 91-113\end{array}$ & 42 & M & $\begin{array}{l}\text { Hemotransfusion } \\
\text { Homosexualism }\end{array}$ & + & 13 & $\begin{array}{l}\text { Loss weight, fever, } \\
\text { diarrhea, pulmonary } \\
\text { infection, Kaposi's sarcom }\end{array}$ & Focal neurologic deficit \\
\hline $\begin{array}{c}7 \\
N 93-041\end{array}$ & 24 & M & Hemotransfusion & + & 24 & $\begin{array}{l}\text { Loss weight, fever, } \\
\text { diarrhea,pneumocystosis, } \\
\text { digestive hemorrhage }\end{array}$ & $\begin{array}{l}\text { Focal neurologic deficit, } \\
\text { convulsion }\end{array}$ \\
\hline $\begin{array}{c}8 \\
N 95-163\end{array}$ & 33 & $\mathrm{~F}$ & $\begin{array}{l}\text { Hemotransfusion } \\
\text { Promiscuous }\end{array}$ & + & 36 & $\begin{array}{l}\text { Loss weight, fever, } \\
\text { diarrhea }\end{array}$ & $\begin{array}{l}\text { Focal neurologic deficits, } \\
\text { convulsion, headache, } \\
\text { vomiting, meningeal } \\
\text { syndrome, coma }\end{array}$ \\
\hline $\begin{array}{c}9 \\
\text { N95-205 }\end{array}$ & 50 & M & - & - & 4 & - & $\begin{array}{l}\text { Focal neurologic deficit, } \\
\text { headache, vomiting, } \\
\text { cerebellar syndrome }\end{array}$ \\
\hline $\begin{array}{c}10 \\
N 96-326\end{array}$ & 49 & $\mathrm{~F}$ & - & - & 4 & - & $\begin{array}{l}\text { Focal neurologic deficit, } \\
\text { paraplegy, vomiting, pain } \\
\text { in inferior extremities, } \\
\text { visual hallucinations, } \\
\text { dysfunction of sphincter }\end{array}$ \\
\hline
\end{tabular}

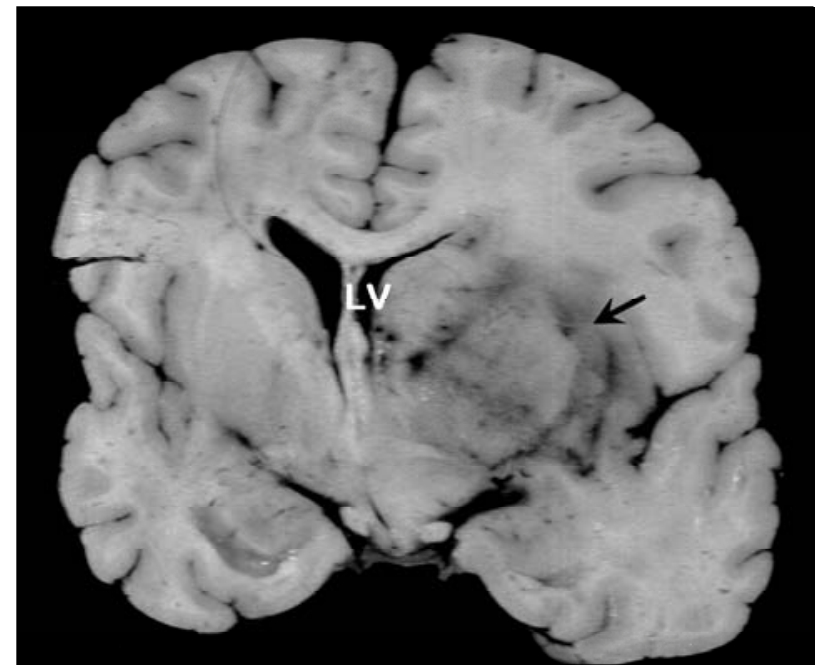

Fig 1. Tumoral involvement of basal nuclei (arrow), with hyper emic halo and compression of the lateral ventricle (LV) and deviation of the central structures.

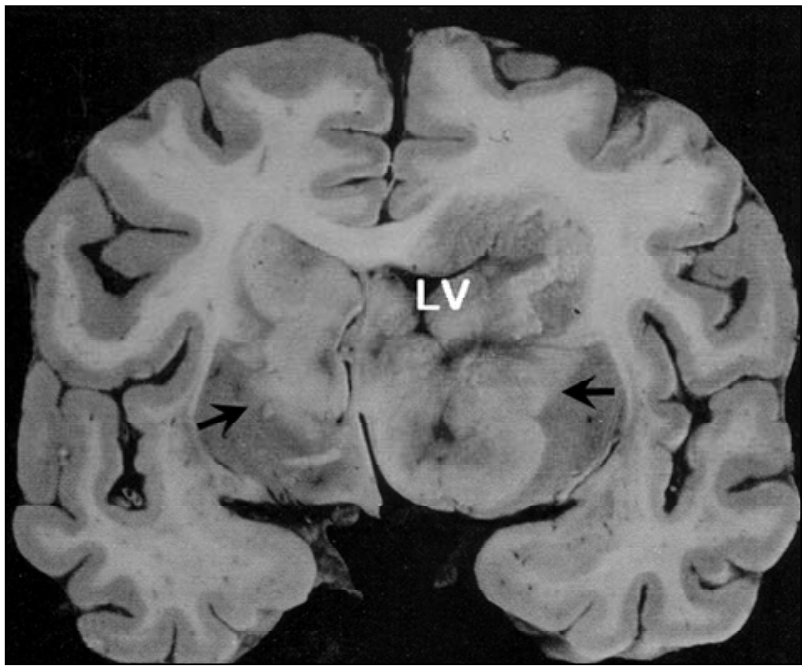

Fig 2. Bilateral tumoral masses in the basal nuclei (arrow) and the corpus callosum, with compression of the lateral ventricle. 
Table 3. Gross findings at of 10 autopsy cases of CNS primary lymphomas.

\begin{tabular}{|c|c|c|c|c|c|c|c|}
\hline Case & External exam & $\begin{array}{l}\mathrm{N}^{\circ} \text { tumoral } \\
\text { lesions }\end{array}$ & $\begin{array}{l}\text { Lobar } \\
\text { lesion }\end{array}$ & $\begin{array}{l}\text { Basal } \\
\text { nuclei }\end{array}$ & $\begin{array}{c}\text { Cerebral } \\
\text { trunk }\end{array}$ & $\begin{array}{l}\text { Cerebellar } \\
\text { hemisphere }\end{array}$ & $\begin{array}{c}\text { Size } \\
\text { (major lesion) }\end{array}$ \\
\hline 1 & Cortical atrophy / old infarct & 3 & - & 1 & 1 & 1 & $1.5 \times 1.0 \mathrm{~cm}$ \\
\hline 2 & Congestion & 1 & 1 & - & - & - & $<1.0 \mathrm{~cm}$ \\
\hline 3 & NL & 1 & - & - & - & - & $<1.0 \mathrm{~cm}$ \\
\hline 4 & Oedema / cerebral hernia & 2 & - & 1 & 1 & - & $4.0 \times 3.5 \mathrm{~cm}$ \\
\hline 5 & Oedema / cerebral hernia & 1 & - & 1 & - & - & $6.0 \times 4.0 \mathrm{~cm}$ \\
\hline 6 & Cortical atrophy & 2 & - & 2 & - & - & $2.0 \times 2.0 \mathrm{~cm}$ \\
\hline 7 & $\begin{array}{l}\text { Cortical atrophy } \\
\text { Cavitary lesion }\end{array}$ & 2 & 2 & - & - & - & $2.0 \times 1.5 \mathrm{~cm}$ \\
\hline 8 & Cortical atrophy & 4 & - & - & - & 2 & $3.0 \times 2.5 \mathrm{~cm}$ \\
\hline 9 & Mild oedema & 4 & - & 2 & 1 & 1 & $5.0 \times 4.0 \mathrm{~cm}$ \\
\hline $10 *$ & Mild oedema & - & - & - & - & - & - \\
\hline
\end{tabular}

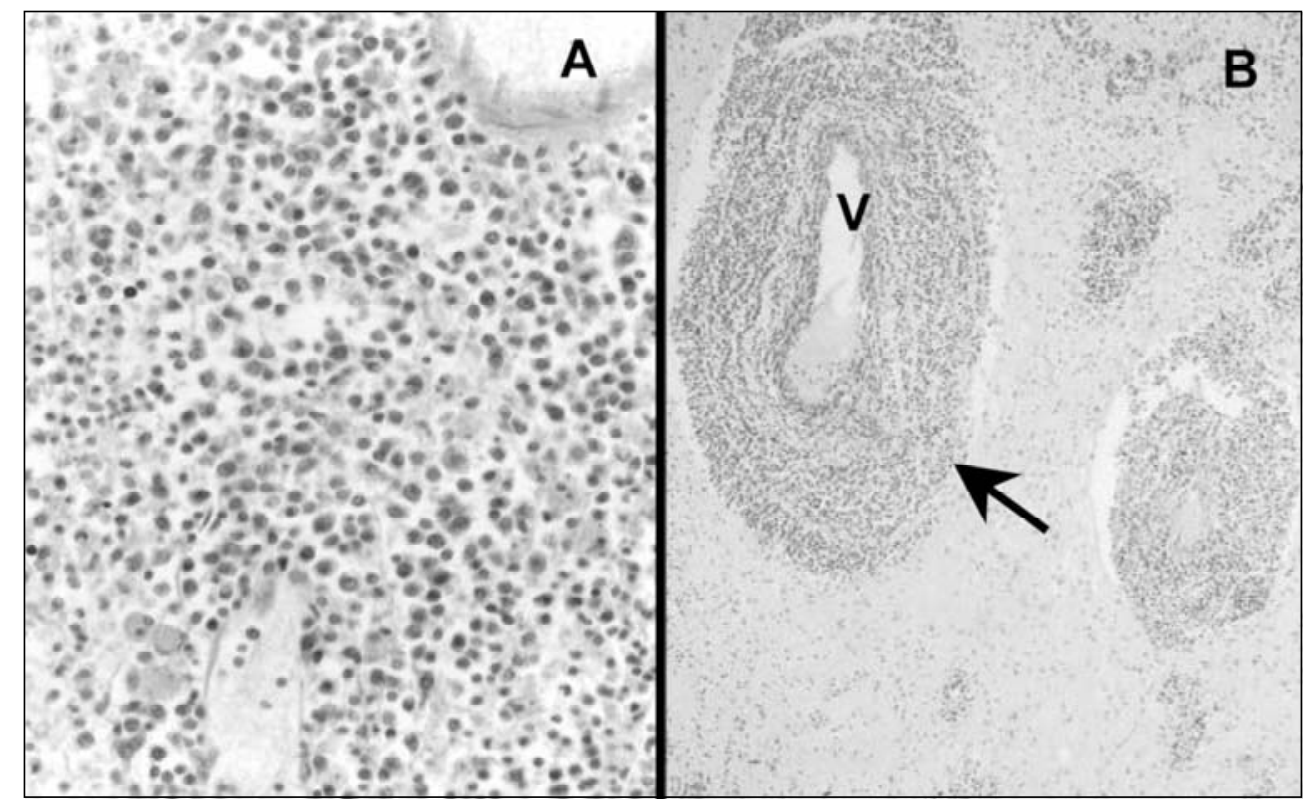

Fig 3. Histopathology of the non-Hodgkin large B-cell lymphoma. (A) Note dense sheet of typical lymphocytes (HE; 40x). (B) Angiocentric pattern (arrow; V) of the tumoral involvement (HE; $5 x$ ).

various sections did not reveal any parenchymal abnormalities.

Other important associated macroscopic findings were cortical atrophy in four cases and cerebral edema accompanied by uncal and tonsillar herniation in two (Table 3).

Microscopic findings -Microscopic examination revealed densely cellular parenchymatous lesions in nine cases (Fig 3A). These lesions were characterized by atypical lymphoid cells, a central area of necrosis and an angiocentric pattern at the periphery of the infiltrate (Fig 3B), with a rich reticulin network dis- sociating the vascular wall. Only one case did not present the angiocentric arrangement.

In most cases, infiltration was diffuse and consisted of a polymorphic infiltrate comprised predominantly by large, sometimes bi- or multinucleated, immunoblast-like cells containing large, pleomorphic, vesicular nuclei, clearly visible nucleoli and scarce cytoplasm. The mitotic count was high. In two cases the cellular infiltration was made up by small lymphoid cells with inconspicuous mitotic activity. Plasma cell differentiation was also observed in one case (Table 4).

Gliosis was identified in all cases, especially at the 
Table 4. Classification and histopathologic findings at of 10 autopsy cases of CNS primary limphoma.

\begin{tabular}{lccccc}
\hline Case & Classification (REAL) & Necrosis & $\begin{array}{c}\text { Angiocentric } \\
\text { pattern }\end{array}$ & $\begin{array}{c}\text { Subependimal } \\
\text { infiltration }\end{array}$ & $\begin{array}{c}\text { Associated } \\
\text { infections }\end{array}$ \\
\hline 1 & Lymphoplasmacytic NHL (low grade) & Yes & Yes & Yes & No \\
2 & Diffuse large cell NHL & Yes & Yes & No & HIV-E \\
3 & Diffuse large cell NHL & Yes & Yes & No & No \\
4 & Diffuse large B-cell NHL & Yes & Yes & Yes & HIV-E \\
5 & Diffuse large cell NHL & Yes & Yes & Yes & No \\
6 & Diffuse large B-cell NHL & Yes & Yes & Yes & CMV-E \\
7 & Diffuse large B-cell NHL & Yes & Yes & Yes & Treated toxoplasmosis \\
8 & Diffuse large B-cell NHL & Yes & Yes & Yes & CMV-E \\
9 & B-lymphoblast precursor NHL & No & No & Yes & No \\
10 & Peripheral T-cell NHL & No & Yes & No & No \\
\hline
\end{tabular}

NHL, non-Hodgkin's lymphoma; HIV, human immunodeficiency virus; CMV, cytomegalovirus; E, encephalitis.

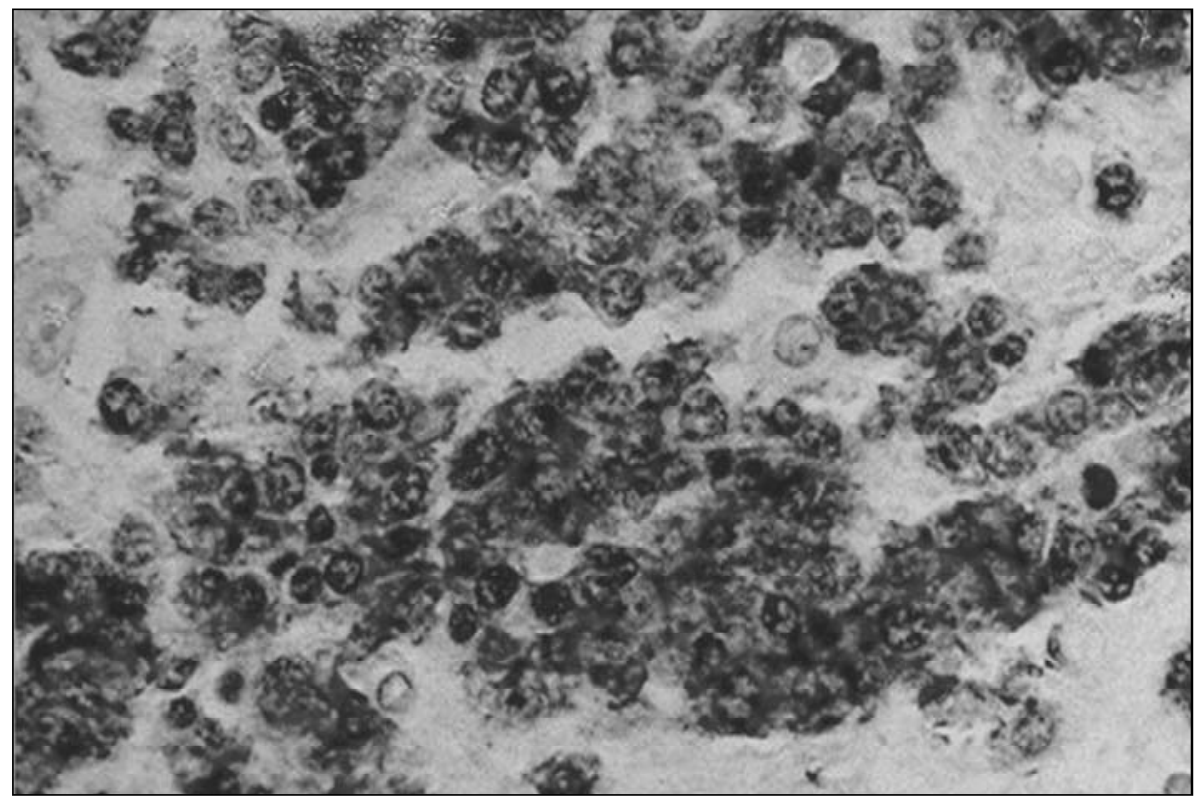

Fig 4. Immunoreactivity of the neoplastic lymphoid cells for CD20. Note strong membrane pattern of positivity (IHC; 40x).

periphery of the tumoral mass, and reactive astro cytes were eventually observed within the tumor tissue.

Associated disorders - Opportunistic infections were observed in six cases: HIV-encephalitis $(n=2)$, CMV - encephalitis $(n=2)$, cerebral toxoplasmosis $(n=1)$ and cerebral cryptococcosis $(n=1)$ (Table 4$)$.

Immunohistochemical findings - All cases but one showed a B phenotype (CD20 positive); the remaining case, from a HIV negative patient, was positive for T-lymphocytes (CD3 positive). In addition, just one case was $C D 30$ positive and one case EBV positive (Fig 4).

According to the REAL classification ${ }^{26}$, three cases were classified as diffuse large B-cell non-Hodgkin's lymphoma, one case as lymphoplasmacytic non-Hodgkin's lymphoma, one case as B-lymphoblast pre c u rsor non-Hodgkin's lymphoma, and one case as peripheral T-cell non-Hodgkin's lymphoma, not otherwise specified. The three cases, in which no immunohistochemistry could be performed, were classified as probably diffuse large B-cell lymphoma. 


\section{DISCUSSION}

In the present study, all tumors were only identified in the CNS, in agreement with the criteria for the diagnosis of PCNSL which require that no lymphomas are detected in organs other than the CNS or posterior region of the retina at the onset of neurological symptoms $\mathrm{s}^{11,14}$. By definition, extranodal lymphomas are recognized as lymphoid tumors arising from lymphoid cell-containing sites other than the lymph nodes ${ }^{27}$.

Macroscopically, the lesions were similar to those of toxoplasmosis, a finding also reported by Cirilo and Rosenblum ${ }^{15}$. Similarly, neuroimaging does not permit a differential diagnosis with cerebral toxoplasmosis ${ }^{4}$ and other methods are necessary for diagnosis conclusion ${ }^{28}$. Thus, in the present study, the diagnosis of PCNSL was made only by microscopy.

In the present study, immunohistochemistry for EBV revealed only one positive case in an AIDS patient. The lack of detection of the virus might have been due to the long time of fixation of the brain which might have inactivate epitopes therefore compromising the testing.

Association with other CNS disorders was a frequent finding in the present series. It might be speculated as proposed by Aderson et al. ${ }^{20}$ and Aozasa et al. ${ }^{21}$ that the presence of HIV- or CMV-induced encephalitis is responsible for B-cell hyperreactivity.

PCNSL continue to be a challenge in terms of their morphology and oncogenesis. Molecular studies of oncogenes and suppressor genes are still inconclusive. These lymphomas develop in non-lymphoid organs without lymphatic vessels, and as such represent one of the main areas of neuro-oncological research.

Acknowledgment - Thanks to Maria C. Aparecida do Nascimento for secretarial assistance. The investigation was carried out at the Department of Pathology, Fluminense Federal University (FFU), University Hospital Antônio Pedro. It was financed by CAPES and based on a master dissertation from the Inter-institutional Post-Graduate Course of FFU and State University of Health Sciences of Alagoas.

\section{REFERENCES}

1. Mead GM, Bleehen NM, Gregor A, et al. A medical researdh council randomized trial in patients with primary cerebral non-Hodgkin lymphoma: cerebral radiotherapy with and without cyclophosphamide, doxorubicin, vincristine and prednisone chemotherapy. Cancer 2000; 89:1359-1370

2. Castellano-Sanchez AA, Li S, Qian J, Lagoo A, Weir E, Brat DJ. Primary central nervous system posttransplant lymphoproliferative disorders. Am J Clin Pathol 2004;121:246-253.

3. Bacchi CE, Bazan R, Padovani EG, et al. Central nervous system lymphoma: association with Epstein-Barr virus. J Bras Patol 1996;32:103109.
4. Berger JR. Mass lesions of the brain in AIDS: the dilemmas of distinguishing toxoplasmosis from primary CNS lymphoma. AJNR 2003;24: 554-555.

5. Okano M, Gross TG. A review of Epstein-Barr virus infection in patients with immunodeficiency disorders. Am J Med Sci 2000;319:392-396.

6. Morgello, S. Pathogenesis and classification of primary central nervous system lymphoma: an update. Brain Pathol 1995;5:383-393.

7. Levy JA, Bredesen DE, Rosenblum ML. Neurological manifestations of AIDS: experience at UCSF and review of the literature. J Neurosurg 1985;62:475-495.

8. O'neill BP, Illig JJ. Primary central nervous system lymphoma. Mayo Clin Proc 1989;64:1005-1020.

9. Murray K, Kun L, Cox J. Primary malignant lymphoma of the central nervous system: results of treatment of 11 cases and review of the literatura. J Neurosurg 1986;65:600-607.

10. Berger JR. Mass lesions of the brain in AIDS: the dilemmas of distinguishing toxoplasmosis from primary CNS lymphoma. AJNR 2003; 24: 554-555.

11. Hochberg FH, Miller DC. Primary central nervous system lymphoma. J Neurosurg 1988;68:835-853.

12. Julien J, Vital C, Rivel J, et al. Primary meningeal B lymphoma presenting as a subacute ascending polyradiculoneuropathy. J Neurol Neurosurg Psychiatry 1991;54:610-613.

13. Lantos PL, Vanderberg SR, Kleihues P. Tumours of the central nervous. In Graham D, Lantos PI (eds). Greenfield's Neuropathology. 6. ed. Hodder Headline Group. Londres, 1997:583-879.

14. Grant JW, Isaacson P. Primary central nervous system lymphoma. Brain Pathol 1992;2:97-102.

15. Ciricillo SF, Rosenblum ML. Use of CT and MR imaging to distinguish intracranial lesions and to define the need for biopsy in AIDS patients. J Neurosurg 1990;73:720-724.

16. Isaacson PG, Norton AJ. Lymphomas of the nervous system. In Isaacson PG, Norton AJ (eds). Extranodal lymphomas. New York: Churchill Livingstone, 1994:217-227.

17. Lachance DH, O'neill BP, Macdonald DR, et al. Primary leptomeningeal lymphoma: report of 9 cases, diagnosis with immunocytochemical analysis, and review of the literature. Neurology 1991;4:95-100.

18. Kalimo H, Lehto M, Näntö-Salonen K, et al. Characterization of the perivascular reticulin network in a case of primary brain lymphoma. Immunohistochemical demonstration of collagen types I, III, IV and V; laminin; and fibronectin. Acta Neuropathol (Berl) 1985;66:299-305.

19. Hoang-Xuan, Khe A, Camilleri-Broet Sophie B, Soussain Carole C. Recent advances in primary CNS lymphoma. Curr Op Oncol 2004; 16:601606.

20. Alderson L, Fetell MR, Sisti M, Hochberg F, Cohen M, Louis DN. Sentinel lesions of primary CNS lymphoma. J Neurol Neurosurg Psychiatry 1996;60:102-105.

21. Aozasa K, Saeki K, Horiuchi K, et al. Primary lymphoma of the brain developing in a boy after a 5-year history of encephalitis: polymerase chain reaction and in situ hybridization analyses for Epstein-Barr virus. Hum Pathol 1993;24:802-805.

22. Rosenblum ML, Levy RM, Bredesen DE, et al. Primary central lymphomas in patients with AIDS. Ann Neurol 1988;23(Suppl):S13-S16.

23. Paulus W, Jellinger K, Hallas C, Ott G, Müller-Hermelink HK. Human herpesvirus- 6 and Epstein-Barr virus genome in primary cerebral lymphomas. Neurology 1993;43:1591-1593.

24. Aboody-Guterman K, Hair L, Morgello S. Epstein-Barr virus and AIDSrelated primary central nervous system lymphoma: viral detection by immunohistochemistry, RNA in situ hybridization, and polymerase chain reaction. Clin Neuropathol 1996;15:79-86.

25. Camilleri-Broet S, Davi F, Feuillard J, et al. and The French Study group for HIV-Associated Tumors. AIDSrelated primary brain lymphomas: histopathologic and immunohistochemical study of 51 cases. The French Study Group for HIV-Associated Tumors. Hum Pathol 1997;28:367-374.

26. Harris N, Jaffe E, Stein H, et al. A revised European-American classification of lymphoid neoplasms: a proposal from the international lymphoma study group. Blood 1994;84:1361-1392.

27. Knowles DM. The extranodal lymphoid infiltrate: a diagnostic dilemma. Sem Diagn Pathol 1985;2:147-151.

28. Skiest DJ, Erdman W, Chang WE, Oz OK, Ware A, Fleckenstein. SPECT thallium-201 combined with toxoplasma serology for the presumptive diagnosis of focal central nervous system mass lesions in patients with AIDS. J Infect 2000;40:274-281. 